IRA-International Journal of Management \& Social Sciences

ISSN 2455-2267; Vol.06, Issue 02 (2017)

Pg. no. 147-154

Institute of Research Advances

http://research-advances.org/index.php/RAJMSS

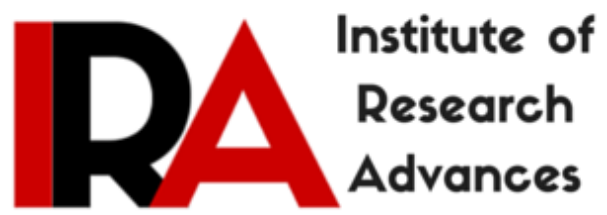

\title{
Effectiveness of MBO-Comparative Analysis of LIC and HDFC Insurance
}

Dr. Khushdip Kaur

Khalsa College for Women, Civil Lines, Ludhiana, India.

Type of Review: Peer Reviewed.

DOI: http://dx.doi.org/10.21013/jmss.v6.n2.p3

\section{How to cite this paper:}

Kaur, K. (2017). Effectiveness of MBO-Comparative Analysis of LIC and HDFC Insurance. IRAInternational Journal of Management \& Social Sciences (ISSN 2455-2267), 6(2), 147-154. doi:http://dx.doi.org/10.21013/jmss.v6.n2.p3

(C) Institute of Research Advances

\section{(oc) EY-NC}

This work is licensed under a Creative Commons Attribution-Non Commercial 4.0 International License subject to proper citation to the publication source of the work.

Disclaimer: The scholarly papers as reviewed and published by the Institute of Research Advances (IRA) are the views and opinions of their respective authors and are not the views or opinions of the IRA. The IRA disclaims of any harm or loss caused due to the published content to any party. 


\begin{abstract}
$M B O$ is a dynamic process whereby the superiors and the subordinates of an organization jointly identify its goals define each individual's major areas of responsibility in terms of results expected and use these measures to assess the contribution of its members in the development of organization. MBO increases the value of communication, which will lead to an increase in the successful completion of goals in the business settings. As a performance appraisal technique It also affects the different aspects relating to job like promotion, Increments, placement and transfer, improving performance, self-development and setting higher goals for the future. The MBO method is supposed to enhance organizational effectiveness by getting the organization to become more result focused. Present paper focuses on how far the practice of $M B O$ is helpful in improving the performance of employees, their self-development and setting higher goals for the future in LIC and HDFC. Helpfulness of MBO in enhancing communication between superior and subordinate is also examined in the paper.
\end{abstract}

KEY WORDS: MBO, Setting of Goals, Self -Development, Improving Communication

\title{
INTRODUCTION
}

Management by Objectives (MBO) is an excellent tool for improving administrative efficiency in a conducive organizational environment of transparency, accountability, responsiveness and good governance. It is a powerful and dynamic system of management.

Management by objective is one of the techniques by which executives can improve organizational performance and effectiveness. The idea of MBO was contributed by Donaldson Brown and Alfred Sloan in 1920 and Edward Hagenin in 1930s. Peter Drucker, a noted management writer introduced the term MBO in 1954 Drucker said "the manager must know and understand what the business goals demand of him in terms of perform once and the superior needs to understand what he expects of his subordinate mangers. The subordinate intern needs to be able to know what in the way of results he should hold himself accountable for". According to his SMART goals evaluation scheme, objectives should be specific, achievable, measurable, realistic and time-bound.

According to Rodgers and Hunter, MBO contains three main characteristics "participation in decision making, goal setting and objective feedback". Participation is used to create common perception for organization as a whole. Goal setting entails "the continuous review and revision of objectives" while objective feedback is the tool for managers to assess subordinates on progress toward goal achievement.

The development of $\mathrm{MBO}$ in the nineteen-sixties significantly enhanced the possibility of providing opportunities to the managers to participate in setting their own goals, in planning their own work and in monitoring, appraising, controlling and improving their own performance. It has provided a wider perspective and given a deeper meaning to appraisal. It has lead to a system of appraisal which facilitates the integration of the manager's personal goals with the goals of the organization.

MBO is one of the Rational School of Management's successful products .It is also called as "Management by Results" which is concerned with the joint participation of subordinate and superior in the establishments of clear and specific objectives for each individual and unit.

\section{REVIEW OF LITERATURE}

Researchers at the University of Kitencky found MBO programme introduced by the top management had a more positive effect on the satisfaction of the managers needs than a programme introduced by the personnel department. In the approach top managers not only used MBO in their jobs but also trained their subordinates in the MBO process. 
In 1957, Douglas McGregeor, a scholarly writer on management in his classic paper, while criticizing trait appraisal system, strongly pleaded for appraising on the basis of present objectives, which lend good and constructive criteria of evaluation. According to his thinking this will foster the development of subordinates and motivate them for future performance.

In the review of the research literature devoted to MBO, Robert Rogers and John E. hunter examined 70 reports that included quantitative evaluation of MBO programs. Their findings showed productive gains in 65 out of seventy evaluation studies. The average productive increase was $47 \%$, while cost data showed an average saving of $26 \%$. Employee attendance was shown to improve by $24 \%$.

In a1991 comprehensive review of thirty years of research on the impact of Management by Objectives, Robert Rodgers and John Hunter concluded that companies whose CEOs demonstrated high commitment to $\mathrm{MBO}$ on average a $56 \%$ gain in productivity. Companies with CEOS who showed low commitment only saw a6\%gain in productivity.

MBO plays the vital role as a practical management tool in shaping organization membership. Various researches have been done MBO to find its strength and weaknesses.

Poister and Streib(1995) conducted the study of municipal government: Variation on traditional management tool. This study examined the application of MBO throughout local government in U.S. The results of this study suggested that MBO was still an effective tool and widely implemented in the local government.

In the study of Communicating management by objectives, Olthoff, R. \& Hogendoorn, M. (1999) indicated that by planning objectives, communication between managers and subordinates will be efficient. The authors revealed that "goal setting increases the value of communication, which will lead to an increase in the successful completion of goals in the business settings"

Regarding subordinate's participation in goal setting Merrit and Berger(1998) interviewed 22 managers and executives in hospitality industry to determine the utility in goal setting. Their results indicated that goal setting provided a great opportunity for these people to manage both themselves and their subordinates.

Poister and Streib (1995) conducted the study of municipal government: Variation and traditional management tools. This study examined the application of MBO throughout local government in US. The results of the study suggested that MBO was till an effective management tool and widely implemented in the local government.

In the study of communication of MBO, Olthoff, R. and Hogendoorn, M.(1999)indicated that by planning objectives, communication between managers and subordinates will be efficient. The authors revealed that "goal setting increases the value of communication, which will lead to an increase in the successful completion of goals in the business settings"

MBO systems are worthy of further investigations since they can improve organizational effectiveness. The three major components of the MBO process (i.e. goal setting, participation in decision making, and objective feedback) are separately and together as a system shown to yield increases in organizational productivity.(Kondrasuk,1981;Rodgers and Hunter,1991)

\section{OBJECTIVES OF THE STUDY}

1. To study the effect of MBO as a performance appraisal technique on different aspects like promotion, increments and transfer. 
2. To examine how far the practice of MBO is helpful in "improving the performance", "self development", "setting higher goals for the future" and "dealing directly to work related problems"

3. To study the extent of helpfulness of MBO in enhancing communication between superior and subordinate.

\section{SCOPE OF THE STUDY}

Scope of the study was limited to various branch offices of LIC \& HDFC Insurance situated in Ludhiana district.

\section{RESEARCH METHODOLOGY}

The study is primarily based upon primary data collected through questionnaire comprising of questions related to: How MBO as a performance appraisal technique affects the different aspects relating to job like promotion, Increments, placement and transfer; Helpfulness of MBO in improving the performance, self-development and setting higher goals for the future.

Convenient sampling method was used to collect data from the 40 respondents of LIC and 40 respondents from HDFC Insurance. Mean, standard deviation, T- values, F-ratio were calculated to statistically analyze the data.

\section{ANALYSIS AND DISCUSSION}

MBO process provides sound criteria for evaluating the performance of employees and helping the organization to plan strategies, goals and targets. It is necessary that every employee of the organization should have proper knowledge of prevalent performance appraisal methods like MBO used in their organization.

\section{Effect of MBO on different Aspects}

MBO can be viewed as a motivation technique, being made up of objectives setting, participation and feedback. When viewed as performance appraisal technique, it encourages a systematic goal oriented, accurate and objective performance evaluation, based on the degree of accomplishment of specific objectives.

Respondents were asked how the MBO as a performance appraisal technique affect the different aspects relating to job.

\section{Promotion}

Promotion which constitutes upgrading of the employees status and salary plays a significant role in motivating the employees. It adds to employees' social status and group relatedness. It fulfills his desire for achieving distinction. 


\begin{tabular}{|l|l|l|l|l|l|}
\hline \multicolumn{7}{|l|}{ TABLE 1: Effect of appraisal through MBO on different aspects } \\
\hline Aspects & LIC & \multicolumn{1}{l|}{ HDFC Insurance } & t-value \\
\hline & Mean & SD & Mean & SD & \\
\hline Promotions & 2.18 & 0.5 & 2.7 & 0.52 & $4.56^{* * *}$ \\
\hline Increment & 2.38 & 0.63 & 2.8 & 0.41 & $3.53^{* * *}$ \\
\hline Placement \& Transfer & 1.53 & 0.55 & 2.28 & 0.6 & $5.83^{* * *}$ \\
\hline F-ratio & $9.58 * * *$ & & $11.37 * * *$ & & \\
\hline C.D. & 0.5328 & & 0.3763 & & \\
\hline
\end{tabular}

Table 1 shows that mean value of HDFC Insurance is higher than mean value of LIC. The $t-$ value(t=4.56) shows that regarding promotion there is a significant difference in the views of LIC respondents and HDFC Insurance respondents at $1 \%$ level of significance. The study revealed that objectives of HDFC Insurance are more achievable with better results.

Results of a survey conducted in North Indian Synthetic, yarn producing organization by Manish Aggarwal also advocated that in order to make performance appraisal system effective, it should be linked with promotions and individual development.

\section{Increments}

In most of the organizations, salary grades are associated with the positions held by officials in an organization. Annually the salary of every employee increases by fixed amount associated with that grade. In some companies increments are not given until the performance appraisal report of that employee is received from his superior. Mean value of HDFC Insurance is higher than mean value of LIC as shown in the Table 1 .The $\mathrm{t}$-value $(\mathrm{t}=3.53)$ shows that there is a significant difference among the respondents of LIC and HDFC Insurance regarding the 'increment' at $1 \%$ level of significance. It revealed that objectives of HDFC Insurance are more realistic and achievable with better results.

\section{Placement and Transfer}

Table 1 shows that mean value of HDFC Insurance is higher than mean value of LIC. The $t$-value(t=5.83) highlights significant difference between the respondents of LIC and HDFC Insurance at 1\% level of significance regarding 'placement and transfer'. The results revealed that a majority of respondents believe that the decision of' placement and transfer' of individuals is a net result of assessment through MBO.

The F-ratio value(9.58)of LIC shows that there is a significant difference among the different aspects that are affected by appraisals through MBO among LIC respondents. The study revealed that they give more importance to 'increment' in comparison to 'promotion' and 'placement \& transfer.' The F-ratio value (11.37) of HDFC Insurance shows that the opinion of respondents differ with regardto different aspects affected by appraisals through MBO. The study revealed that more weightage is given to 'increment' as compared to 'promotion' and 'placement \& transfer'. In his study Rao (1984) indicated that for Indian managers, rewards and recognition seem to be more emotionally satisfying than growth needs. Consequently, if rewards were delinked from appraisals, then employees would pay less attention to 
appraisal process this would result in reduced satisfaction with the appraisal system and also give poor returns to the HRD departments.

\section{HELPFULNESS OF MBO}

MBO creates an urge within, rather stimulates the manger to improve his level of working in accordance with status he occupies, and the emoluments he draws. Responses were sought from the employees whether MBO as a method of performance appraisal is helpful in (1) improving performance (2) selfdevelopment (3) setting higher goals for the future 4) dealing directly to work related problems.

\section{Improving performance}

Table 2 shows that the mean value (2.63) of HDFC Insurance is higher than the mean value of LIC(2.18). the $t$-value $(t=3.84)$ shows that regarding the improvement of performance the views of respondents of HDFC Insurance significantly differ from the views of LIC at $1 \%$ level of significance. It revealed that the respondents of HDFC Insurance consider it more helpful in improving competency level of individuals

TABLE 2 Helpfulness of practice of MBO

\begin{tabular}{|c|c|c|c|c|c|}
\hline \multirow[t]{2}{*}{ Helpfulness } & \multicolumn{2}{|c|}{ LIC, India } & \multicolumn{2}{|l|}{ HDFC } & \multirow[t]{2}{*}{ t-value } \\
\hline & MEAN & $\mathrm{SD}$ & MEAN & SD & \\
\hline Improving the Performance & 2.18 & 0.45 & 2.63 & 0.59 & $3.84 * * *$ \\
\hline Self-development & 2.08 & 0.62 & 2.8 & 0.41 & $6.13 * * *$ \\
\hline Setting higher goals for future & 1.83 & 0.75 & 2.78 & 0.42 & $6.99 * * *$ \\
\hline Dealing directly to work related problems & 1.68 & 0.8 & 2.3 & 0.65 & $3.80 * * *$ \\
\hline F-ratio & $7.86 * * *$ & & $8.54 * * *$ & & \\
\hline C.D. & 0.2197 & & 0.2471 & & \\
\hline
\end{tabular}

Rogers and Hunter (1992) conducted the meta analysis of MBO application in both public and private sector, resulting that $100 \%$ of public sector studies reported performance gain after the introduction of MBO. Their findings pointed what high commitment to $\mathrm{MBO}$ from top management will create significant gain, and $\mathrm{MBO}$ in both public and private sectors was highly effective.

\section{Self- Development}

One of the important aspects of MBO is as a device for increasing worker's personal involvement in their mutual goal-setting process with their superiors, which contributes to providing job satisfaction and motivate them towards improved performance.

Table2 shows that mean value of LIC is different from the mean value of HDFC Insurance. The t-value $(t=6.13)$ shows that there is a significant difference with regard to self- development among the HDFC respondents and LIC respondents at $1 \%$ level of significance.

Few managers responded that through this appraisal technique individuals are motivated to highlight their training need and career development needs which help them in self- development. 


\section{Setting higher goals for the future}

According to $\mathrm{t}$-value shown in Table $2(\mathrm{t}=6.99)$ states that the responses of LIC employees are significantly differ from the responses of employees of HDFC Insurance with regard to 'setting higher goals for the future'. Participation in goal-setting and review of performance provide an insight and experience to a person that what care he has to take while deciding about the future goals.

\section{Dealing directly to work related problems}

Performance appraisal through MBO help the person to deal directly with work related problem by defining his job in clear terms, well detailing the major responsibilities associated with his job and what performance is expected, and further telling him how his job relates to the organization's work scheme as a whole.

The $\mathrm{t}$-value $(\mathrm{t}=3.80)$ given in the Table 2 shows a significant difference in the responses given by the respondents of LIC and HDFC Insurance at $1 \%$ level of significance.

F-ratio(7.86) of LIC in the table describes that the views of LIC respondents differ among the various aspects relating to helpfulness that is provided by $\mathrm{MBO}$ as a performance appraisal method. They had the opinion that MBO helps a lot in 'self-development' as compared to other aspects.

F-ratio (8.54) of HDFC Insurance in the table shows that the respondents of HDFC Insurance had the opinion that MBO helps more in 'setting the higher goals for the future' than the other aspects.

\section{ENHANCING COMMUNICATION}

MBO helps developing a structure, through a network of communication process in an organization that can most effectively contribute to goal setting and their accomplishments by the members of the organization.

Table 3 shows the responses of employees of LIC and HDFC Insurance regarding the extent of helpfulness of $\mathrm{MBO}$ in enhancing communication between superior and subordinate.

Figures given in the table reveal that $25 \%$ of the respondents of LIC and $72.50 \%$ respondents of HDFC Insurance believe that $\mathrm{MBO}$ helps in enhancing communication between superior and subordinate to the maximum extent. Only 5\% of the employees of HDFC Insurance responded that it helps to enhance communication to low extent where as large percentage of employees of LIC that is $55 \%$ believe that MBO enhances communication to low extent.

Table 3 Extent of helpfulness of MBO in enhancing communication

\begin{tabular}{|l|l|l|l|l|}
\hline \multicolumn{4}{|l|}{ Extent of helpfulness of 'Management by Objectives' in enhancing communication } \\
\hline Extent of service & LIC, India & HDFC & \\
\hline & No. & \%age & No. & \% age \\
\hline To maximum extent & 8 & 20 & 29 & 72.5 \\
\hline To some extent & 10 & 25 & 9 & 22.5 \\
\hline To low extent & 22 & 55 & 2 & 5 \\
\hline Mean & 1.65 & & 2.68 & \\
\hline SD & 0.8 & & 0.57 & \\
\hline t-value & & $6.63 * * *$ & & \\
\hline
\end{tabular}


The $t$-value( $t=6.63)$ shows that the opinion of respondents of LIC is significantly differ from the opinion of respondents of HDFC Insurance. Figures reveal that HDFC Insurance have more supportive and participative environment as compared to LIC. There is healthy relationship among the subordinate and superior.

\section{CONCLUSION}

It can be concluded that MBO is a dynamic process whereby the superiors and the subordinates of an organization jointly identify its goals, define each individual's major areas of responsibility in terms of results expected and use these measures to assess the contribution of its members in the development of organization. It motivates and enables the managers to grow and to develop their own capabilities through a process of achievement of the company goals. It is used as a tool for strategic planning, employee motivation and performance enhancement. MBO is a motivator because it meets employee needs for esteem, self-actualization, growth and power achievement. MBO empowers employees to increase responsibility with an opportunity for creating meaningful, challenging work to help them grow and accomplish what they and the manager want to accomplish.

\section{References}

1. Drucker, Peter F. People and Performance, William Heinman Ltd. 1977, Chapter- MBO and self -control, pp. 430-442.

2. Drucker, Peter F. The Practice of Management. Reissue Edition. Collins, 26 May 1993

3. Guleck, Coleman F. In Micheal Beer and Robert A. Beck (ed.) The PersonalAdministration-Book of Readings, p.177.

4. McGregor, Douglas, “An Uneasy look at performance Appraisal”,Harvard Business Review, June, pp.87-94.

5. Odiorne, S. George, MBO II: A system of Managerial Leadership for the 80s, Arnold Heinman Publications(India), 1983.

6. Robert Rodgers and John E. Hunter,Impact of Management by Objectives onOrganizational Productivity, Journal of Applied Psychology, Vol.76(2),April 1991, pp322-336

7. Robert Rodgers and John E. Hunter,A Foundation of Good Management Practicein Government: Management by ObjectivesPublic Administration Review

Vol. 52, No. 1 (Jan. - Feb., 1992), pp. 27-39

8. Tossi, H.L. and Carroll, S.J. "Managerial Reactions to Management byObjectives" Academy of Management Journal, No.4 December 1968, pp. 415-426. 